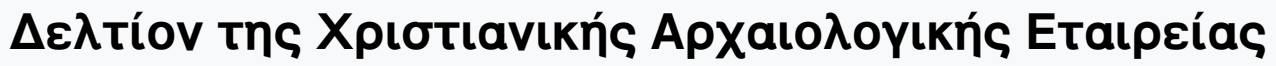

Tóp. 4 (1966)

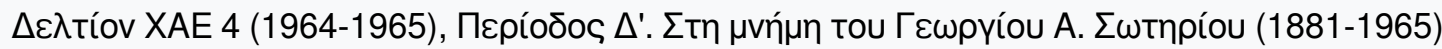

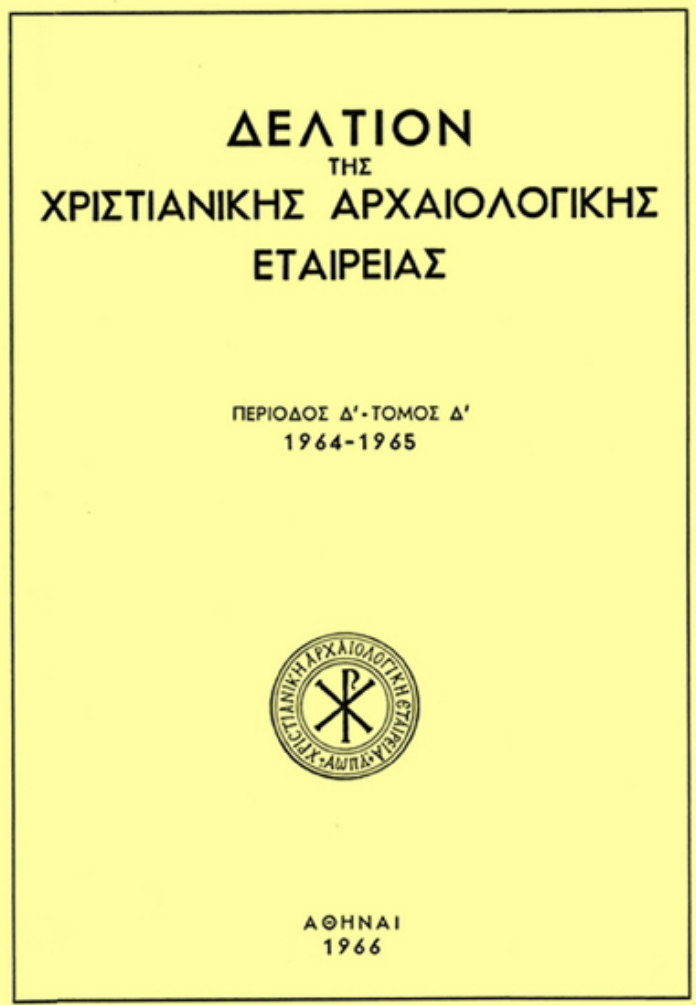

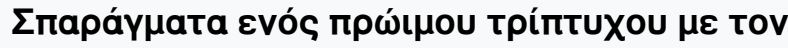

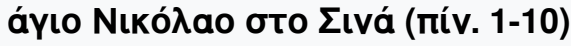

Kurt WEITZMANN

doi: $\underline{10.12681 / \text { dchae.751 }}$

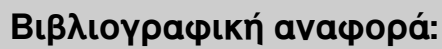

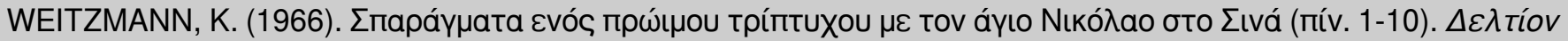

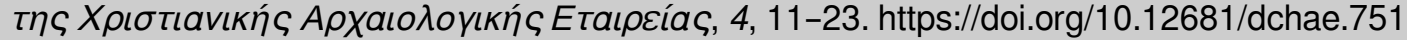




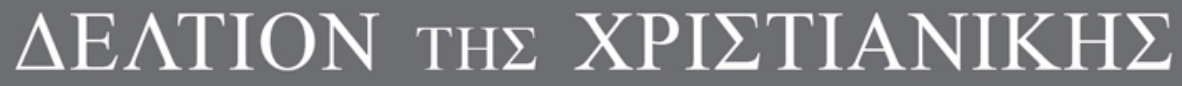 APXAIO $\Lambda$ OГIKH $\Sigma$ ETAIPEIA $\Sigma$}

Fragments of an early St. Nicholas triptych on Mount Sinai (pl. 1-10)

Kurt WEITZMANN

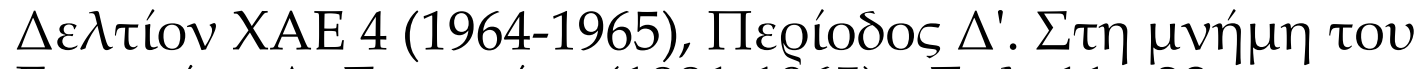

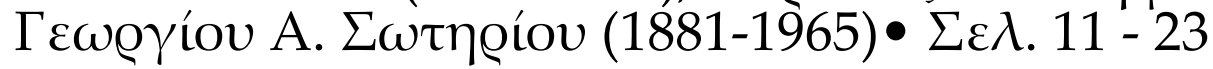

A@HNA 1966 


\section{FRAGMENTS OF AN EARLY ST. NICHOLAS TRIPTYCH ON MOUNT SINAI}

(PI. 1 - 10)

Not since the days of Kondakoff has our knowledge of Byzantine art been so broadened by a single person as it has been by George Sotiriou. If, out of his lifework, which covers every conceivable branch of Byzantine art and archaeology, we should mention only the latest of his many publications, the one of Sinai icons, which he published jointly with Mrs. Sotiriou ', it is solely for the reason that the present study proposes to make an addition to their selection. This publication may well be considered their most influential one in the future. They had clearly realized that Sinai has by far the most important icon collection in existence and that the increasing awareness of icon art, far beyond the interests of Byzantinists, will have to take the Sinai material into account as the basis for all future studies concerning that which, in Byzantine culture, was the central branch of pictorial art. We can think of no more appropriate way of honoring Professor Sotiriou than to add another brick to a building for which he and Mrs. Sotiriou have laid a solid foundation.

\section{I}

Among the numerous Middle - Byzantine icons which became known as a larger group for the first time in the publication of the Sotirious, there is a small, very delicately painted panel with four scenes from the life of St. Nicholas (fig. 1) ${ }^{2}$, which, as we believe, they dated correctly in the eleventh century, localized it in Constantinople and related it to the style of miniature painting of this period ${ }^{s}$.

1. G. et M. S otiriou, Icones du Mont Sinaï, To. I (planches), Athens 1956 ; To. II (texte), 1958.

2. To. I, pl. 46 ; To. II, p. $62-63$.

3 . They give the measurements $15 \times 12 \mathrm{~cm}$. My own vary slightly $15,2 \times 12,5$, but such differences are unavoidable depending at what height you measure a panel with somewhat uneven edges. 
The first scene depicts one of the most familiar events in any Nicholas cycle: the three guiltless generals who were thrown into prison on the basis of false accusations are shown sitting in a semicircle with their feet put in stock'. The Sotirious clearly realized that this compositional scheme was borrowed from an Old Testament scene, namely the Explaining of the Dreams ot the Baker and the Butler by Joseph in prison, as illustrated in the Octateuchs, and very few adjustments were necessary in order to fit the three figures into the new context. While the scenes in the panel have no inscriptions, the Sotirious gave them appropriate titles which presumably were adapted from some later Nicholas icons, where short titles are quite a common feature. The proposed title OI TPEIC A $\Theta \Omega O$ I EN TH $\Phi$ YAAKH fits the situation very well indeed.

The next scene, aptly entitled O AГIOC ENYINIAZsN TON AГION KanCTANTINON, shows St. Nicholas approaching the emperor from behind the bed and informing him of the injustice done to the three generals. Constantine, in full imperial dress and wearing a crown, is turning his head around and leaning it on his right arm in a gesture of sorrow which is not quite called for by the content of this event, but is easily explained if one assumes that in this case, also, the artist made use of an Old Testament compositional scheme. What immediately comes to mind is the encounter of the prophet Isaiah and the sick Hezekiah, a scene very popular indeed in Byzantine miniature painting, since it illustrates one of the Odes attached to the Psalter. A picture of this event is included in the well known manuscript of the homilies of Gregory in Paris, cod. gr. 510, which surely is adapted from an Ode picture $^{2}$, and here Hezekiah is depicted in basically the same pose, turning his head around and supporting it with his arm.

In the case of the third scene we venture to disagree with the Sotirious' interpretation. It shows St. Nicholas, in a composition similar to that of the preceding scene, talking to a man on a couch. The Sotirious believed him to be the poor father of the three girls for whom St. Nicholas provided a dowry to enable them to marry, and conse-

1. For the various versions of the St. Nicholas stories cf. G. A n rich, Hagios Nikolaos. Der Heilige Nikolaos in der griechischen Kirche, Vols. I - II, Leipzig-Berlin 1913-1917. For the story of the three generals cf. esp. Vol. I, p. 66 ff. and passim, Vol. II, pp. 368 ff. and passim.

2. H. O mont, Miniatures des plus anciens Manuscrits Grecs de la Bibliothèque Nationale du VI au XV siècle, Paris 1929, pl. LVII - K. W e i t z m a n n, Illustrations in Roll and Codex, Princeton 1947, p. 149 ff. and fig. 137. 


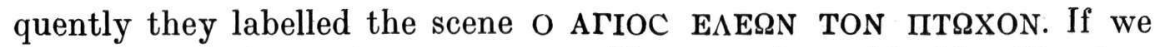
are not mistaken, three reasons militate against this identification. First of all, the episode of the poor father with the three daughters is told in practically all texts as one of the very first events in St. Nicholas' life when, in fact, he was not yet a bishop although in this scene art always depicts him in episcopal vestments. While it is true that the sequence of events is not too precisely observed in these narrative picture series, one would hardly expect it to be the last scene before his death. Secondly, where this episode is depicted within an icon cycle, it shows the poor man imploring Nicholas in front of a bed which is shared by the three daughters, who are really necessary in order to clarify the narration. There is a huge Nicholas icon in the south aisle of the Church (fig. 7 )' ' which shows this scene as described above near the beginning, immediately following St. Nicholas' ordination to the priesthood. Finally, the man on the couch with his bare feet and crippled hand looks more like a sick man to be healed by the Saint than like a pleading father. Why should the impoverished father be lying on a couch at all? There are several healing miracles performed by St. Nicholas of which the one most likely to be depicted on our icon seems to be that of a certain Leon ${ }^{2}$ who was lame and, according to the story, lying before an icon of St. Nicholas and imploring his help, when the Saint appeared to him in a dream, shook him and ordered him to get up. If the representation of our icon is not quite as dramatic as the text might suggest, it is because, once more, a biblical model has been adjusted to this event. In this case one would expect to find a New Testament composition as the source, the most obvious one being the healing of the paralytic by Christ, who in the same Parisian Gregory manuscript previously mentioned, approaches the sick man who is trying to raise himself from the couch in basically the same manner ${ }^{3}$.

The last scene, labelled by the Sotirious тафн тоY АГІоY, likewise shows the burial of the saint in a rather conventional manner, whereby two men are lowering the corpse into a sarcophagus. Here, too, parallels which might have served as models can be found in biblical illustration and the Sotirious have pointed to a burial scene of Gedeon as found once more in the Octateuchs.

1. This icon is dated Ao. 1719 and has the signature of the painter Tsortzis Kastrophylax.

2. An rich, op. cit. Vol. II, p. 440.

3. O m o n t, op. cit., pl. XLVI. 
When one turns the panel around one will notice on its reverse side the lower half of a rather roughly designed cross (fig. 2$)^{1}$ which, in spite of its weak execution, is not necessarily later in date, since it is quite a common feature in Byzantine icon painting to treat the reverse side of a panel with a certain lack of care. The foot of the cross, painted red and embellished decoratively with a rinceaux pattern, extends into two half palmettes, while normally the cross and the leaf work are more sharply differentiated. There can be no doubt that we are dealing here with only the lower half of a panel which originally showed the complete cross. The crossarm must have been immediately above the present cut and in the upper spandrels the beginning of the inscription $\overline{\mathrm{IC}} \overline{\mathrm{XC}}$ which then continues on the preserved part with $N \overline{\mathrm{H}} \mathbf{K} \overline{\mathrm{A}}$. Such decorative crosses are a very common feature indeed and occur in Middle Byzantine manuscripts often in pairs at the back of dedication miniatures, as e. g. in the Paris Gregory cod. $510^{2}$ and the so-called Leo Bible in the Vatican, cod. Reg. grec. $1^{3}$.

We have been fortunate in finding the upper half of the panel (fig. 3 ). In the valley parallel to the one in which St. Catherine's monastery is located there is a small monastery, the Arba'in, dedicated to the Forty Martyrs of Sinai which is no longer inhabited by monks but has only a bedouin caretaker. The church in which services can be and on occasion are still held has a certain number of icons on its walls and in the iconostasis, whose Royal Doors are decorated by two pairs of small heterogeneous icons. One of these four, the upper one in the right valve, is the panel under consideration, while the other three, an angel from an Annunciation (fig. 12), a bust of St. George and a standing Michael are all later and of moderate quality. These icons are firmly glued and nailed into the door valves so that it is impossible to remove them. Thus, we cannot give evidence that the upper half ol the cross is actually on the reverse side of this piece, but in style and measurements " the two fragmentary panels agree so thoroughly that no serious doubts remain.

1. All photographs of Sinai icons published in this article were made during the two campaigns of the Alexandria-Michigan-Princeton Expedition to Mount Sinai in 1958 and 1960.

2. O m o n t, op. cit., pls. XVII - XVIII.

3. Miniature della Biblia Cod. Vat. Regin. greco 1 e del Salterio Cod. Vat. Palat. greco 381 (Collezione Paleogr. Vat. Fasc. 1) Milan 1906, pls. 3 and 6.

4. It measures $22 \times 12,2 \mathrm{~cm}$. The slight difference of $2 \mathrm{~mm}$ in width compared with the other piece is, of course, inconsequential. 
Two more scenes from the life of St. Nicholas fill the lower part of this panel, scenes which we expect to depict events preceding those on the panel already discussed. In the first St. Nicholas, still a youth of tender age and dressed in a deacon's garment, is ordained as a priest by his uncle, the archbishop of Myra. He is stepping forward towards the altar, followed by two fellow deacons, one wearing a pyxis and swinging a censer, the other holding what appears to be a candle. If one searches also in this case for a compositional model one might think of the Presentation of the Virgin in the Temple, where the young Mary is facing the priest and followed by the candle-bearing daughters of Israel. There is one detail, extraneous as it may seem at first glance, which, indeed, seems to strengthen this hypothesis: a structure of many steps rises behind the archbishop, an unusually high presbyter bench with a bishop's throne such as is common in representations of the Virgin's Presentation in the Temple, where she is repeated sitting on the highest step of exactly the same kind of structure in order to receive food from the hand of an angel.

The second scene is an almost exact repetition of the first and depicts the ordination of St. Nicholas as a bishop. Now fully grown and wearing a dark beard, though still smaller in size than all the other figures, St. Nicholas wears the omophorion as a sign of his new rank. The wall behind the altar, the flanking, tower - like buildings and the ciborium, all set against a gold ground, are represented exactly as in the preceding scene, but the presbyter bench is omitted.

Above these two scenes, in a much larger scale and thus quite unrelated to the Nicholas scenes, is a Virgin enthroned, dressed as usual in garments of saturated dark blue and purple red. Gold is used for the highlights of the stately throne bench and for the edge of the mantle. Seated in frontal position she raises the spindle in her left hand and holds the thread in her right. While her body is slightly turned to the right, her head, in a contrappostic movement, is turned to the left in the direction where one expects the angel Gabriel to appear, for there can be no doubt that we are dealing here with the right half of an Annunciation scene. We must assume, therefore, that there originally existed a second panel which depicted the Angel on the upper part and beneath the Angel six more scenes from the life of St. Nicholas, only that the scalloped termination of this tall panel tapered off to the left, thus forming a symmetrical counterpiece. These two panels, then, obviously formed the wings of a triptych, whose central part had a trifoiled termination, and of this triptych only the two parts forming 
one wing are preserved. It is also certain that both these parts belong to the same wing, i. e. the right one: the upper part because of the position of the Virgin, and the lower because the cycle ends in the lower right hand corner with the burial of the Saint.

\section{II}

One wing being completely preserved, there is, of course, no difficulty in reconstructing the triptych in its outline (fig. 5) ${ }^{1}$, while the inner organization, particularly that of the central panel, raises some problems. At the same time one can be certain as to the appearance of the triptych when the wings were closed. The lost left wing must have had a cross exactly like that of the other wing (fig. 4) and we can still appreciate the effect which was given by the placement of two crosses side by side from ivory triptychs, mostly of the tenth century, where sometimes the two wings share a single cross when they are closed $^{2}$, but more often each has its own cross, one exactly like the other ${ }^{3}$. In most cases, the cross is on a pedestal and the half palmettes are a separate entity attached to it, but there is also one instance ${ }^{4}$ in which cross and palmette are fused as in our icon wing. Since this ivory is tenth - century it helps to support the dating of the painted cross into the Middle - Byzantine period.

When one opened the triptych, the main subject of the wings, and perhaps also, as we shall see later, of the center was a narrative cycle of the life of St. Nicholas. Such cycles of small scenes illustrating the life of a certain saint were quite common on single icons where they are placed on the frame, usually beginning at the upper left and ending at the lower right hand corner. No saint's life has been more popular and more frequently depicted in this fashion on icons than that of St. Nicholas. The Sotirious have published what, according to our present knowledge, is most likely the earliest of this type of narrative Nicholas icon (fig. 6) ${ }^{5}$, which they have dated at the end of the twelfth century. Within its cycle of sixteen scenes five of our six occur in such a similar

1. For the drawings of these reconstructions I am indebted to Mr. David T. van Zanten.

2. A. Goldschmidt-K. Weitzmann, Die Byzantinischen Elfenbeinskulpturen des X-XIII. Jahrh. Vol. II, Berlin 1934, pls. II, 8b; IX, 30b; XXVIII, 72b ; XXIX, 73a.

3. Ibidem pls. XV, 38b ; XXXI, 78b ; LXIII, 75b, 155b, 182c, 184b.

4. Ibidem pl. V, 21b.

5. S o tiri o u, op. cit. p. 144 ff. and fig. 165 plus colorplate. 

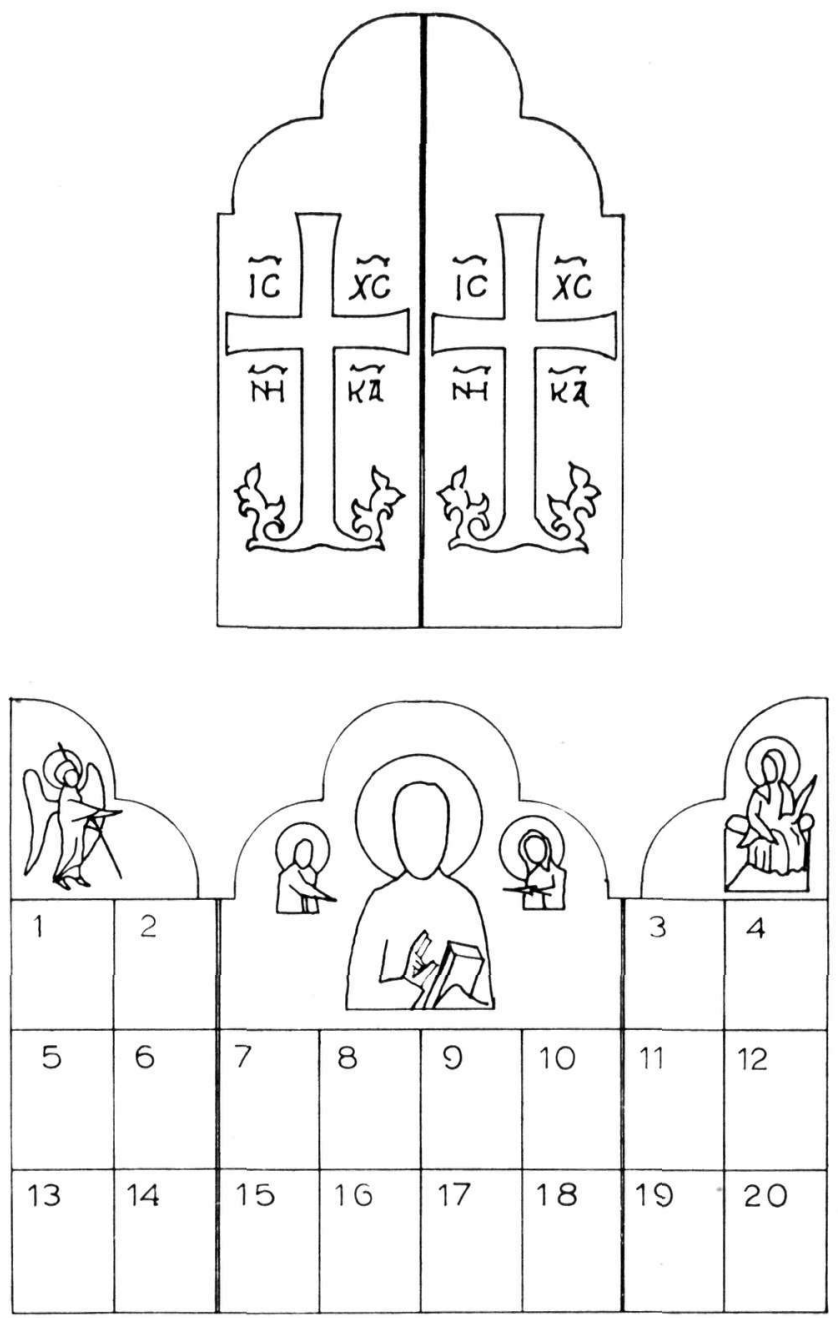

Figs. 4-5. Reconstruction of the closed and open triptych. 
composition that there cannot be the slightest doubt that both go back to the same archetype. The minor differences are essentially stylistic as the scenes on our wing are earlier in date and also they are more elaborate and much more delicately painted. Its slender, ascetic figures show a greater restraint in their movements and a formal elegance somewhat lost in the more stocky figures of the later icon.

The ordination of St. Nicholas as a priest is depicted on the large icon as the third scene in the upper frame. Behind the extensively damaged figure of the Saint only one deacon is visible, holding a pyxis and candle, i. e. the implements which in our icon are carried by two deacons and, as a sign of further abbreviation, the ciborium is omitted. The next scene, his ordination as a bishop, shows the very same condensations and, besides, is rendered in mirror reversal, probably for the purpose of having the scene in the upper right hand corner inverted. In the frame-icon, the scene depicting the three generals in prison is placed as the second scene of the left side. It is quite natural that lateral scenes should have been condensed in width as the upper ones were in height, and this caused the lateral prison towers to overlap the two prisoners who flank the older one seated in the center. In both cycles the dream of Constantine follows, once more in an identical compositional scheme. However - and this is most important - the next scene of our panel which we interpreted as depicting the healing of the lame Leon is not among the sixteen scenes of the frame-icon.

On the basis of this close parallelism we feel justified in using the frame-cycle for the reconstruction of our triptych - cycle. While there can be little doubt that the lost left wing likewise had six scenes beneath an angel of the Annunciation, the problem is whether the triptych was confined to twelve scenes, six on each wing, or whether at least part of the central panel likewise had narrative scenes. In the latter case one should, of course, also try to find a place for the eleven other scenes of the frame-cycle. The belief that the second alternative is the more likely one is supported by the fact that the triptych definitely had one additional scene - the healing of the lame Leon - that is not contained in the frame - cycle and therefore presupposes an even larger cycle as model.

There is nothing canonical about the sixteen scenes of the icon frame. True enough, the Sotirious have published another icon which they attribute to the fifteenth century ${ }^{1}$ and whose sixteen scenes indeed so

1. Ibidem p. 155 ff. and fig. 170 . 
closely follow those of the twelfth - century icon discussed above that most likely it is a direct copy of it, but the Sinai collection also includes the Nicholas icon already mentioned (fig. 7 ) which has no less than twenty - four scenes in the frame. It is true that this icon is very late - it is dated 1719 - but as far as the iconography is concerned, those scenes which illustrate the same events as the earlier icon continue to follow the same tradition, as one glance at the first three scenes - Birth, Education and Ordination - will convince the beholder. Then, however, following as the fourth scene, is the one which we have already mentioned showing the impoverished father with his three daughters (p. 2), one of several scenes not contained in the sixteen scene cycle. On the other hand, the twenty - four - scene cycle does not include every scene of the earlier cycle: the three generals in prison, the cutting of the oak, the burial of the saint and a few others are omitted. This, then, means that when one corroborates the evidence from both sets of illustrations the archetype had even more than twenty - four episodes from the life of St. Nicholas; but since twenty four seems almost the maximum number of scenes for which space could be provided in the frame of a single icon, we conclude that the original cycle was not invented for icon decoration at all but for another medium which could accommodate a larger number of scenes. This, in our opinion, could only have been a miniature - cycle that must have accompanied one or the other of the texts that give a detailed account of the life and miracles of this popular saint. This fully corroborates the observations of the Sotirious who, on the basis of the miniature style of the narrative scenes, had already claimed a close connection with and dependence upon book illumination. We cannot, of course, within the limits of this study, attempt a full reconstruction of the postulated miniature - cycle. This would require the inclusion of many more Nicholas icons even including some later Russian ones. However, it was necessary to outline this problem in order to acquaint the reader with the difficulties and the somewhat hypothetical nature of the proposed reconstruction of our triptych.

All cycles begin in very much the same way, whereby the ordination of Nicholas as a priest, the first scene on our wing (fig. 3 ) is preceded by two others : his birth and his education (figs. $6-7$ ). These scenes, then, must have been depicted on the left wing on the same level, under the figure of the angel Gabriel and are marked Nos. 1 and 2 in our reconstruction sketch, while the two preserved scenes at the right are marked Nos. 3 and 4. One important conclusion can be drawn 
from this arrangement, namely, that no Nicholas scene was depicted on this level in the, central panel. It does not require much imagination to guess what occupied this part of the panel: it could hardly have been anything else but a bust of St. Nicholas which we shall have to discuss later.

However, when one moves to the next zone of the triptych wing, the level on which the three generals in prison and the dream of Constantine are represented (Nos. 11-12), more than two scenes from the frame - icon are available in order to fill the gap, leading us to believe that the narrative sequence must have extended across the central panel, thus linking the pairs of scenes on the wings. If this assumption is accepted, then we would have to accommodate six scenes, Nos. 5-10, in order to reach, with Nos. 11 and 12, the two preserved ones. Normally, the narrative cycles on icon frames read first from left to right at the top, then down the right side, after that down the left side and finally end in the bottom strip. If one followed this rule in the case of our large Nicholas icon, one would have available the four scenes of the right frame and the first scene of the left, i. e. a total of five, in order to fill the six empty spaces of our reconstruction sketch, i. e. Nos. 5-10, until one reaches, with Nos. 11, the prison scene. Yet, in this specific instance, it is not quite so simple. It may be pointed out, e. g., that the second scene of the right frame, which depicts Nicholas appearing in the dream and warning the governor Ablabios, who had imprisoned the three guiltless generals, belongs together with the prison scene on the same level on the left frame, while the fourth scene at the right, the cutting of the oak, interrupts the sequence of the scenes that are connected with the episode of the three generals. Yet, this does not seem to be a case of confusion but rather of a different arrangement according to which the scenes on the sides must be read horizontally instead of vertically, and in this order they actually correspond more closely to the arrangernent of our triptych, i. e. to the more original organization. To support our theory it is interesting to notice that on still another Nicholas icon on Mount Sinai ', which we should like to date in the sixteenth century and which comprises twelve scenes in the surrounding frame, the appearance of Nicholas to Ablabios is transferred to the left frame, directly under the dream of Constantine. This indicates an adjustment of the lateral scenes from a horizontal to a vertical arrangement which does more justice to the unity of

1. Published in color in Time Magazine April 13, 1959, p. 93. 
the four sides of a frame. Our Nicholas icon of the twelfth century (fig. 6) thus takes an intermediary position in the development of the Nicholas icons.

Thus we propose to distribute only four of the frame scenes over the six empty spaces from Nos. 5-10, namely, the first scene at the left which depicts St. Nicholas performing sacred rites and the first three at the right: the expelling of demons during a storm at sea; the previously mentioned appearance of St. Nicholas to Ablabios in the dream, and the three fettered generals before the emperor Constantine. What the two remaining empty spaces might have contained and where they would have to be placed in the sequence, can no longer be ascertained. It is nothing more than a hypothesis to suggest the popular scene depicting the impoverished father (fig. 7, fourth at the top) as one possibility, and for the other, one could think of yet another of the several episodes of distress at sea where St. Nicholas appears as the rescuer (fig. 7, second at the left and last at the bottom ). For the six spaces at the bottom of our triptych, i. e. Nos. 13-18, the five remaining scenes of the frame-icon can claim priority in providing ideas for the subjects they may have contained. They depict, next to the right elbow of St. Nicholas, the three liberated generals who show their gratitude to the Saint, and on the opposite side, the cutting of the oak, followed by the first three scenes in the bottom strip: St. Nicholas liberates the boy who had been abducted by the emir of Crete; he brings the boy back to his feasting parents; and finally, he saves three youths from decapitation. What the sixth panel might have contained and where it was to be placed in the sequence we do not venture to guess.

We have thus arrived at a rather unique arrangement for the earliest narrative cycle of the life of St. Nicholas that we have today. The grouping of the scenes on what unquestionably is the right wing of a triptych fully justifies the attempt to propose a rather uncommon solution. To reiterate, the sequence of the individual scenes cannot be established with complete certainty, and a more thorough study of all the Nicholas icons may eventually improve our present arrangement. Yet, we hope to have established the overall layout with near certainty, thus gaining a new insight into the complex and varied icon production of the eleventh century.

\section{III}

If the central part of the triptych had a bust of St. Nicholas as its dominant feature as we think it is reasonable to assume, then we 
may be permitted to speculate as to how this portrait of the Saint might have looked. The phase not very much later than the purported date of our triptych is well represented by the Nicholas icon of the twelfth century of which we have already discussed the framing cycle (fig. 6). Fortunately, however, the Sinai collection also includes at least two Nicholas icons which, in our opinion, are earlier and, if we are not mistaken, are indeed the earliest known today. One of them (fig. 8) ${ }^{1}$ depicts the church father wearing a pinkish white phailonion and a white omophorion with thin - armed golden crosses and holding a jewel - and pearl-studded golden book. While the bulbous forehead is as prominent as in the twelfth - century icon (fig. 6) the treatment of the flesh and of the framing hair is soft and has not yet acquired the ornamental quality of the later representation; it does not yet have the spiral lock and the sharply delineated strands of the beard; the nose is not as long, the cheeks not as sunken and the eyes not as staring. In short, the face is more lively and closer to nature. It is an icon of high quality and the restraint in the coloration and the delicate use of the gold on the garment give an impression of elegance and refinement, whereas the wide solidly golden area of the frame and background, in which the nimbus is incised so as to create an impression of rotation, enhances the hieratic effect.

The second Nicholas bust (fig. 9)" which, like the first one, is inscribed so that its identification is beyond doubt, shows a face less conventionalized than any other known to me. The forehead does not yet have the bulbous form which one usually associates with the standardized portrait of this Saint, the hair is olive - grey and not white, the nose is nearer to normal length and the general impression given is that of a somewhat younger man. The red - brown phailonion matches the rather intense flesh color and the church father appears less aloof and more human, an impression further enhanced by the placing of the hand simply before the breast, omitting the gesture of blessing associated with what one might call the standardized version. For all these reasons, we propose to date this second Nicholas icon a little earlier than the first, and while it is still premature to be too precise in dating icons of this period, we believe that a date still at the end of the tenth or the beginning of the eleventh century is the most likely one.

1. It measures $32 \times 24,8 \mathrm{~cm}$.

2. It measures $43 \times 33,1 \mathrm{~cm}$. 
On its frame some medallion portraits are depicted of the kind which on the most precious icons were executed in enamel cloisonné. At the top we see a Christ medallion flanked by those of Peter and Paul, at the sides four soldier saints, at the left, Demetrios and Theodore, at the right, George and Procopios, and at the bottom the three physician saints, Panteleimon between Cosmas and Damian. The depiction of such medallions in the frame is typical of some of the best eleventh - century icons ${ }^{1}$ and may well go back to the tenth century, to which some of the above-mentioned cloisonné medallions, which as we know for certain served as decorations on icon frames, belong. In the history of Nicholas icons such medallions on the frame mark the stage preceding their replacement by the narrative cycle of the Saint's life.

In the light of these observations, we would assume that our lost triptych center contained a Nicholas bust which, in style, must have belonged between the two earlier ones (figs. 8-9) on the one hand, aud the twelfth century one (fig. 6), on the other, i. e. halfway in the development towards ornamentalization as reached by the latter. Moreover, there is an iconographic feature which distinguishes the latter portrait from the earlier. To the left and right of the Saint's head there are small busts, one of Christ who offers him a jewel - and pearl studded Gospel book, and one of the Virgin who is offering him an omophorion ${ }^{2}$. Our problem is whether or not these busts of Christ and the Virgin, which must have entered the iconography of the Nicholas icons sometime in the eleventh or twelfth century, can be assumed to have been included in our triptych.

The busts are explained by the legend of the thauma Nicaenum ${ }^{3}$ according to which St. Nicholas, while in a rage, boxed the ears of Arius in the presence of the emperor during a session of the Nicaean Council, whereupon he was imprisoned by order of the emperor and deprived of his episcopal insignia. In the night Christ and the Virgin appeared and gave him a Gospel book and an omophorion, whereupon he was released from prison and reinstated in his episcopal office. The eighteenth - century icon with the twenty - four scenes (fig. 7) includes, above the lower right hand corner, first a depiction of the council scene

1. Sotiriou, op cit., figs. 47 and 64 .

2. Ibidem fig. 81 and $\mathrm{K}$. W e it $\mathrm{zm}$ a $\mathrm{n}$, Thirteenth century crusader icons on Mount Sinai, in : Art Bulletin XLV, 1963, p. 195 and fig. 20.

3. A n rich, op. cit., vol. II p. $393 \mathrm{f}$. 
in which St. Nicholas is slapping Arius and underneath a representation of St. Nicholas in prison with the busts of Christ and the Virgin appearing on the cloud banks and offering the above-mentioned gifts. This means that the episode existed as part of a larger narrative cycle and, consequently, that the addition of Christ and the Virgin (fig. 6) is the result of the intrusion of narrative elements into the traditional portrait bust. This addition, then, was most likely made at the time when the narrative cycle became associated with the icon tradition. Thus, we assume that the Nicholas bust, which we postulate for our triptych center, already had the additions of Christ and the Virgin and that it may very well have been, if not the earliest, at least one of the earliest portraits ever to make this accretion.

\section{IV}

What still needs to be explained is the association of the Annunciation with the Nicholas cycle and its placement at the top of the wings whereby the Virgin and the Angel became separated. On many icons and single panels, as well as on diptychs and triptychs of the Middle-Byzantine period, the Annunciation is the first scene in the cycle of the twelve great feasts, to be followed by other feast scenes, but as such it was never divided into two parts as it is in our case. Yet, there are other cases, beginning very early in icon painting, where an Annunciation, in another context, is indeed divided into two parts and distributed over the wings of a triptych.

In the Sinai collection there is a pair of wings of considerable dimensions (fig. $10 \mathrm{a}-\mathrm{b}$ )' which, together with the lost central part, must have given a very stately impression when opened, forming almost a perfect square. Executed in encaustic technique, the badly damaged surface is partly flaked and partly rubbed off, and yet enough remains to determine the subject matter, with the aid of inscriptions in a strong yellow color on blue ground, and to judge the style. Each wing is divided into two zones, of which the upper one is occupied by the Annunciation and the lower one by two standing saints. The saint at the left, in frontal position, is placed before a low wall, not unlike the four saints on a similar pair of wings published by the Sotirious ${ }^{2}$ and dated by them into the seventh - eighth centuries. However, the figures on

1. Each wing measures $64,8 \times 17 \mathrm{~cm}$.

2. Op. cit., pp. 36 ff. and pls, 21 and 23 plus colorplate. 
our wings are taller and more agile and there seems to be no reason to date them any later than the seventh century.

At the upper left the Virgin is depicted in front of a green wall wearing the customary deep blue and purple garments and moving slightly towards the right. In the lower right hand corner one recognizes a basket in chalice form that contains a ball of purple wool, indicating that the Virgin was, in accordance with the well-known apocryphal story, spinning when the angel approached. On the blue ground the traces of the old fashioned inscription H AГIA MAPIA, in monographic form, are still visible, of which there exist other examples among the early Sinai icons '. Opposite the Virgin the angel Gabriel, clearly inscribed $†$ ГАВPIH $\Lambda$, approaches, set against the same green wall as is the Virgin. Peter (inscribed † о агІос ПЕтРос) осcupies the left side of the lower tier, standing frontally, as already described, before a wall which again is green, and correspondingly at the right Paul (inscribed חAY $[\mathrm{OC}]$ ) is shown in a rather agitated striding position and in his left hand holding what appears to be a large Gospel book. His blue and red garments, better preserved than those of Peter, are strongly highlighted in a very free manner and not very elegant, but at the same time not yet as patternized as those of the four saints of the triptych wings mentioned above. To the right of Paul's hip one notices the head of a brown bull, and color spots at the same level at the left suggest that there was another one. Moreover, at the upper left there is a head, the only one at least partially preserved, belonging to a person behind Paul who is looking up at him. Thanks to the inscription $\Theta \mathrm{EKAA}$ in the upper right hand corner, the meaning of this composition is quite clear. The Acts of Paul and Thecla give an account of how, after a fierce lioness had left Thecla unharmed, the governor bound her by the feet between two bulls in order to have her torn apart; but a fire burned through the ropes and set her free. She then departed to Myra to find Paul who was preaching there. Our picture, then, is a conflation of these two events from the apocryphal Acts of Paul. Thus, we learn that in this pre - iconoclastic triptych the Annunciation was associated with a different iconographical realm and that the only connection it has with our Nicholas triptych is a rather formal one : its placement in the upper parts of triptych wings.

In order to demonstrate that we are dealing here not with isolated

1. Op. cit. pls. $24,25,28$. 
cases but with a familiar subject of triptych decoration that persists throughout the history of icon painting, I should like to introduce a later example of a completely preserved triptych (fig. 11) ${ }^{1}$ which we propose to date in the second half of the thirteenth century. This date is based on its close stylistic relationship with a group of icons made by Crusader artists at about that time in Palestine, probably in Acre. The piercing, rolling eyes and the incised patterns of the nimbi, are some of the characteristic trademarks of this particular group of icons, of which a very considerable number has been preserved on Mount Sinai ${ }^{2}$. In its outline the triptych is very similar to ours as we have reconstructed it (fig. 5) except that the trifoil is changed in its apex into a gothic ogee which indicates the impact of the Crusader's taste. Otherwise, however, in form, program and style, the Byzantine elements prevail. In an upper zone the central panel depicts the Deesis and in the lower zone a row of seven saints, Onouphrios, Nicholas, John Chrysostom, Basil, Gregory of Nyssa, Sabas and Anthony, while the Annunciation is the dominant subject of the wings, with the Virgin and the Angel in much larger scale than the figures in the center. The Virgin, seated on a jewel-studded throne, and once more occupied with spinning is, indeed, quite similarly conceived as in the panel from the Arba'in (fig. 3), except that her body is turned more towards the angel. Thus we may surmise that the angel on the lost wing was not much different from that of the thirteenth-century triptych, which in general still follows a Middle-Byzantine tradition except that in the Palaeologan age the architectural background has become richer and more complex.

This third example, which once more connects the Annunciation with different iconographical subject matter, strengthens our thesis that we are dealing here with a tradition in which the Annunciation is obviously quite independent of whatever else is depicted on the triptych. What, then, is the reason for the consistent depiction of the Annunciation on the wings? Here the re-use of the Arba'in panel (fig. 3) leads to the solution of the problem. As mentioned at the beginning, the panel is inserted in the Royal Doors of an iconostasis. When this was done in rather recent times - the iconostasis is quite modern - the left wing of our triptych must already have been untraceable, but within

1. The central panel measures $48 \times 35,1 \mathrm{~cm}$, the left wing $42,5 \times 17 \mathrm{~cm}$ and the right one $43,5 \mathrm{~cm} \times 17 \mathrm{~cm}$.

2. For the establishing of this group cf. the article quoted on p. 13 note 2. 
ПINA $\Xi 1$

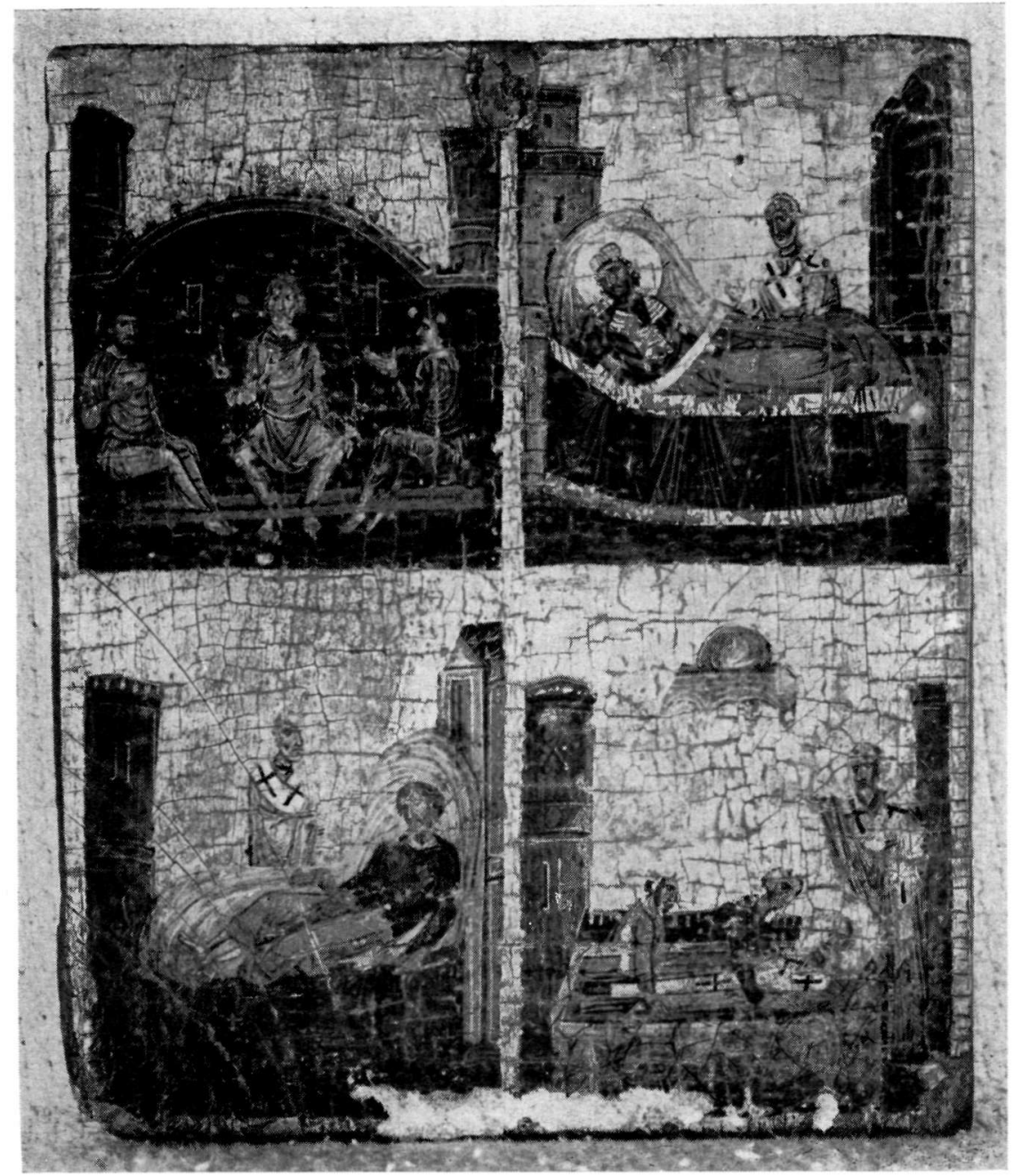

Fig. 1. Mt. Sinai. Scenes from the life of St. Nicholas. 
ПINA $\Xi 2$

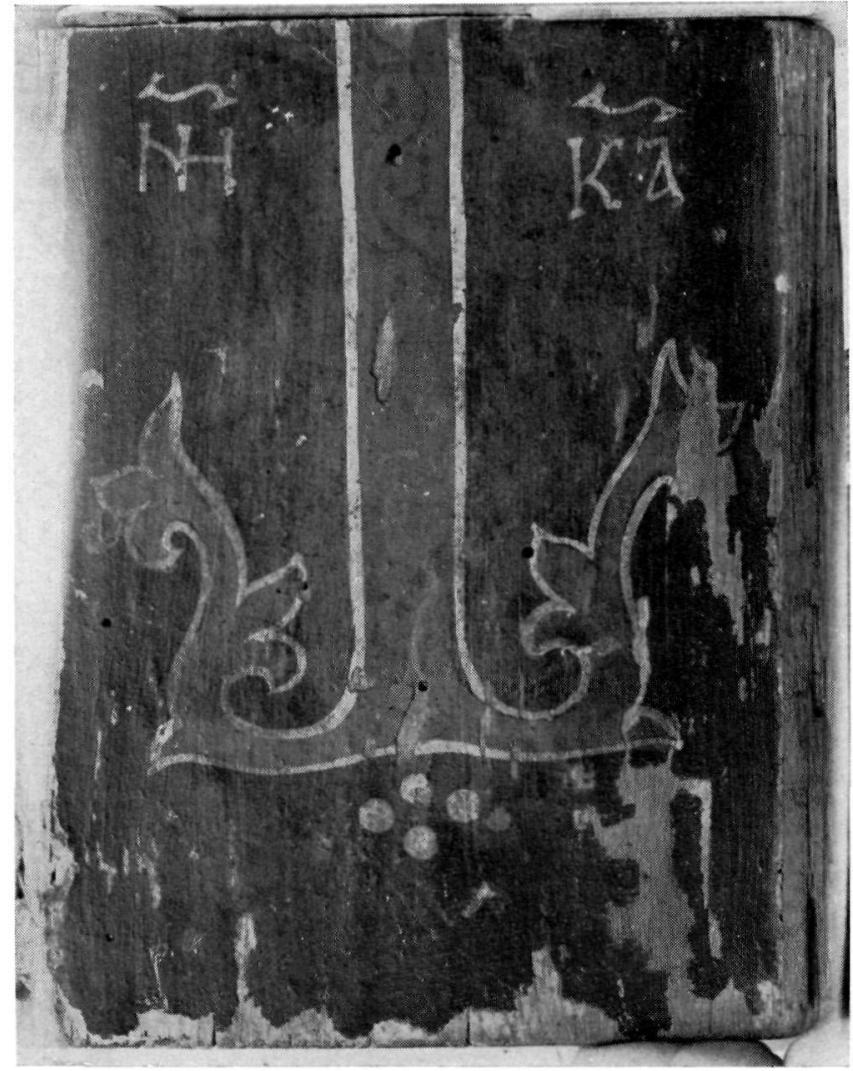

Fig. 2. Same. Seen from the back. 
ПINA $\Xi 3$

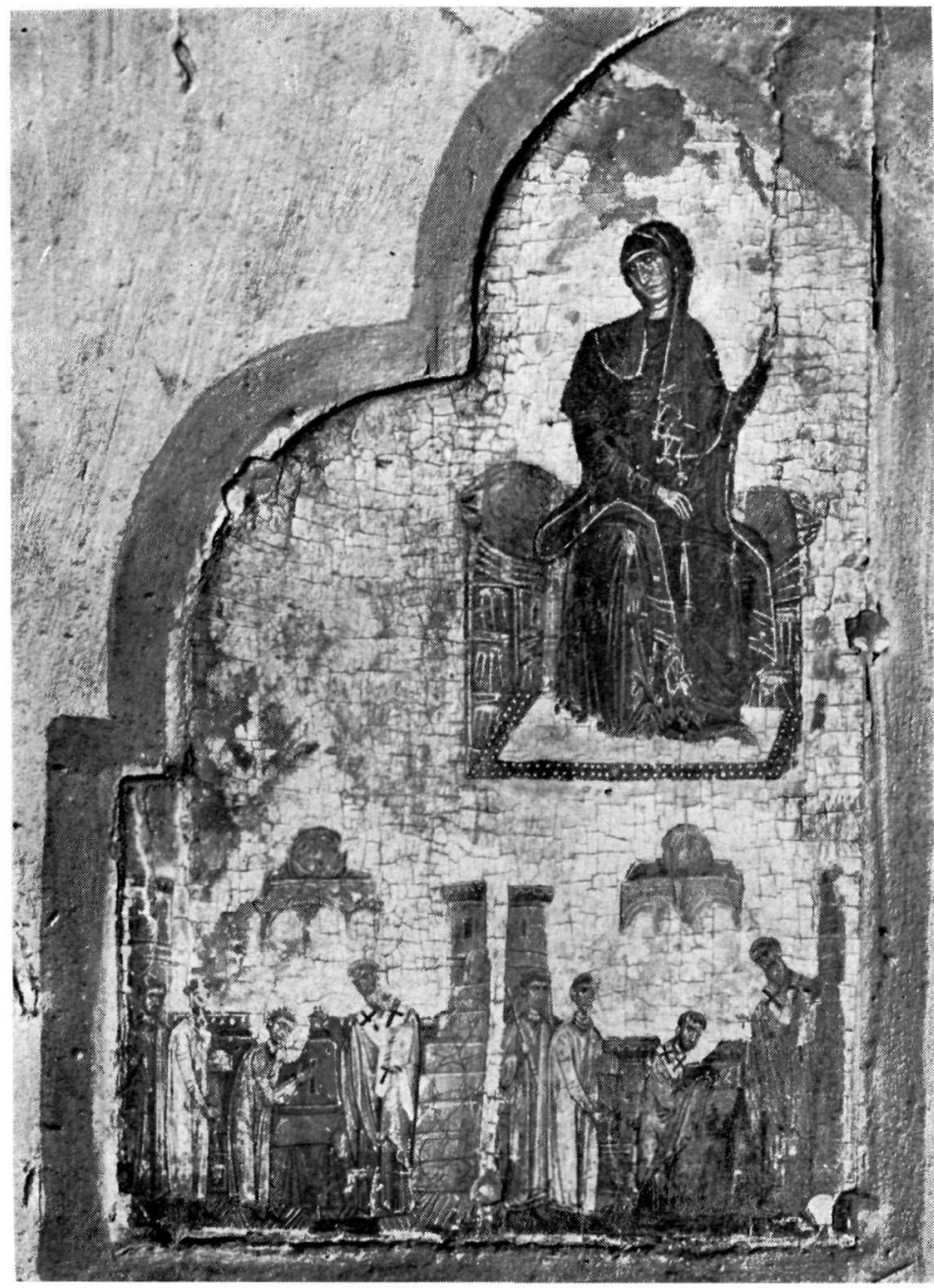

Fig. 3. Mt. Sinai, Arba'in.

Virgin and scenes from the life of St. Nicholas. 


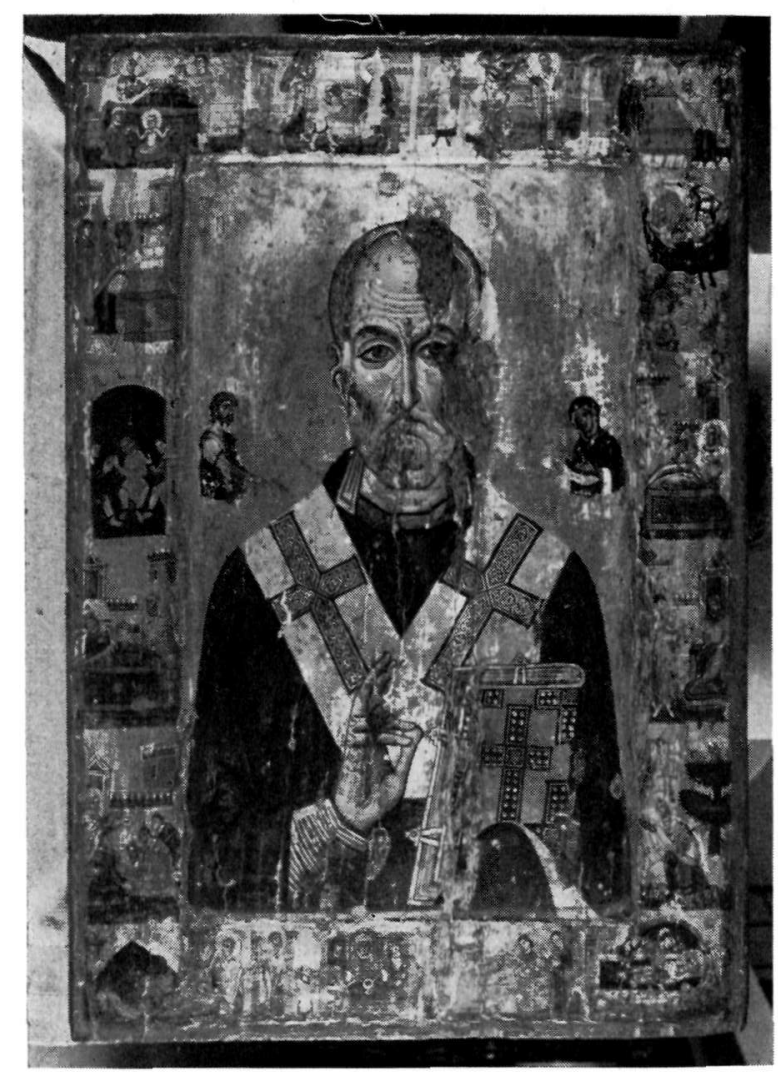

Fig. 6. Mt. Sinai. Icon of St. Nicholas.

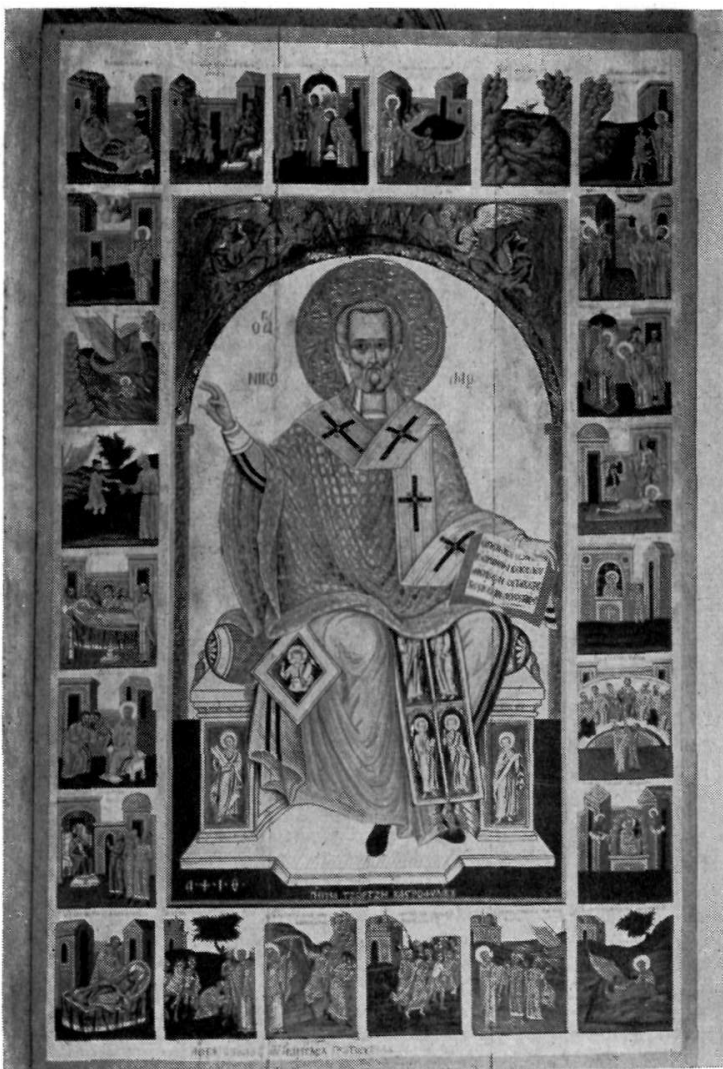

Fig. 7. Mt. Sinai. Icon of St. Nicholas. 


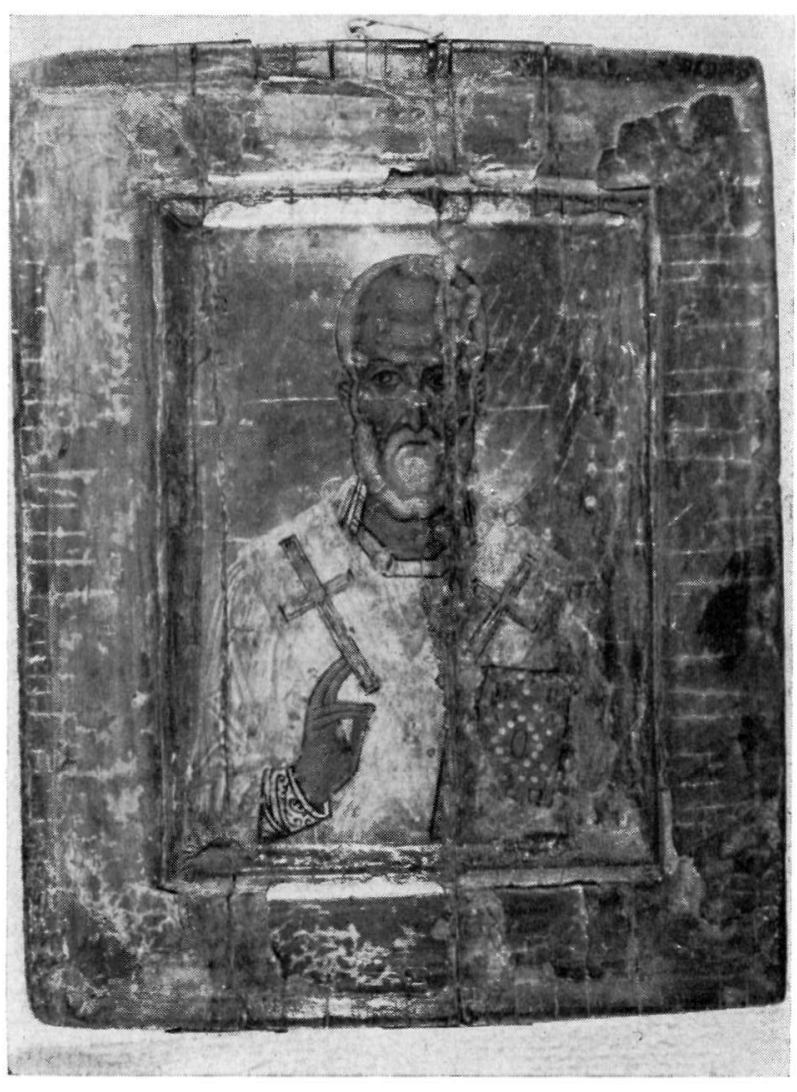

Fig. 8. Mt. Sinai. Icon of St. Nicholas.

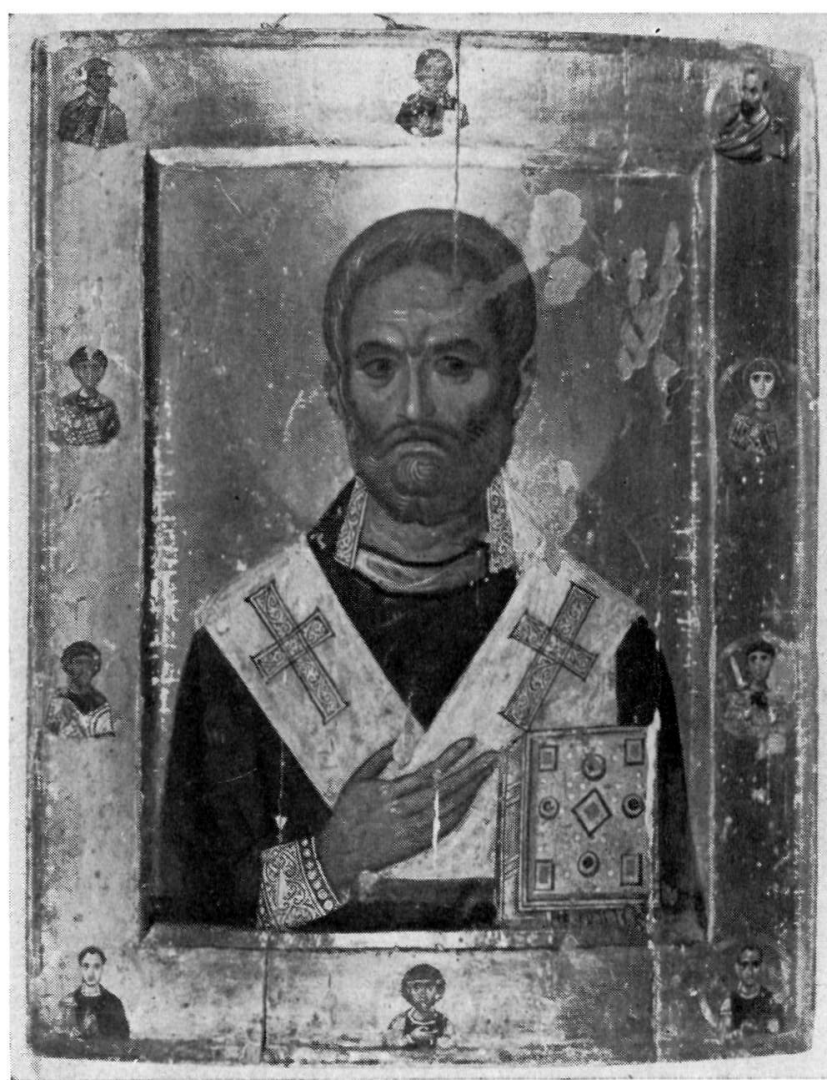

Fig. 9. Mt. Sinai. Icon of St. Nicholas. 


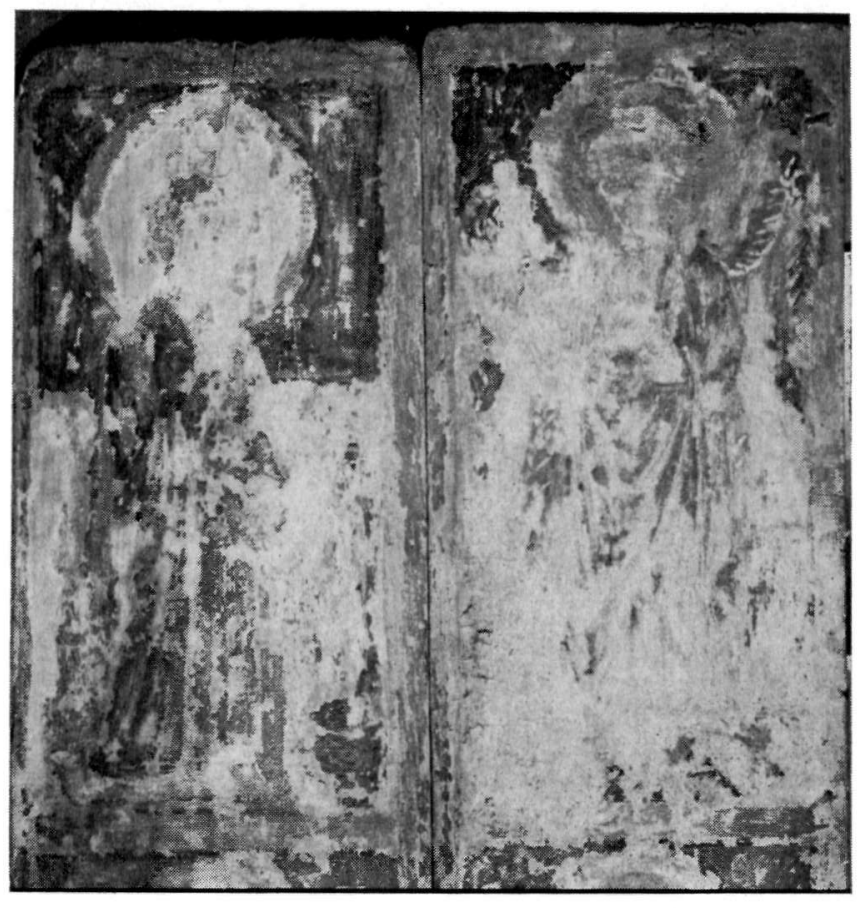

a

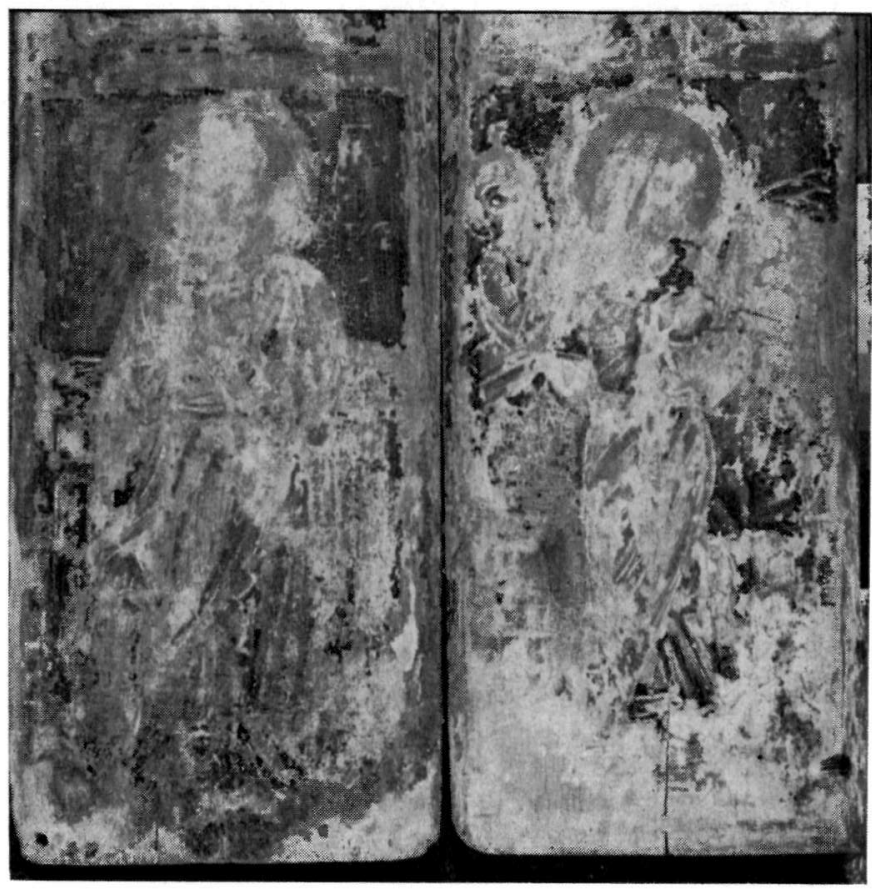

b

Fig. 10 a - b. Mt. Sinai. Triptych wings with Annunciation, Peler aud Paul. 

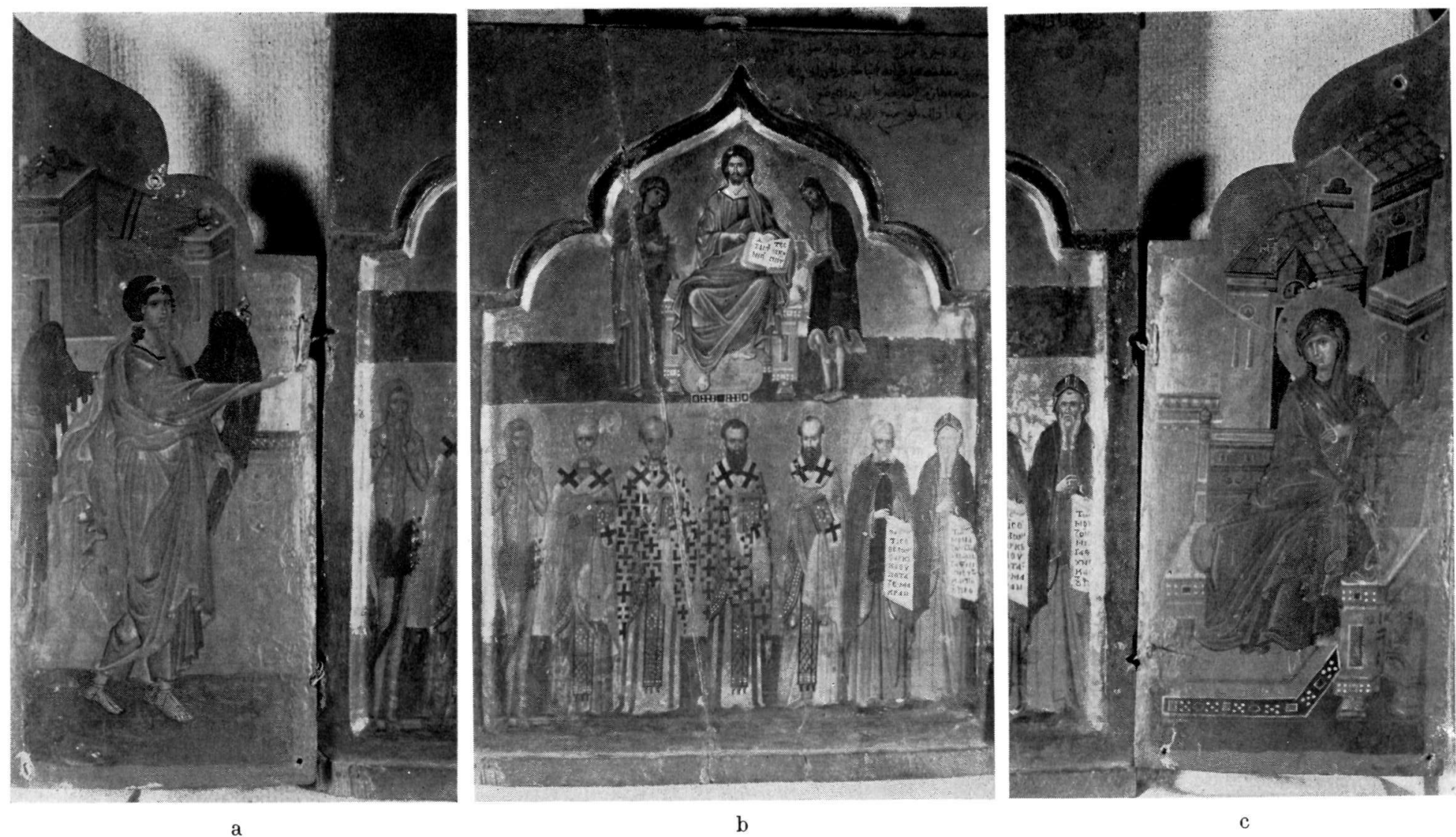

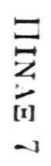

Fig. 11 a-c. Mt. Sinai. Triptych with Deesis, Saints and the Annunciation. 


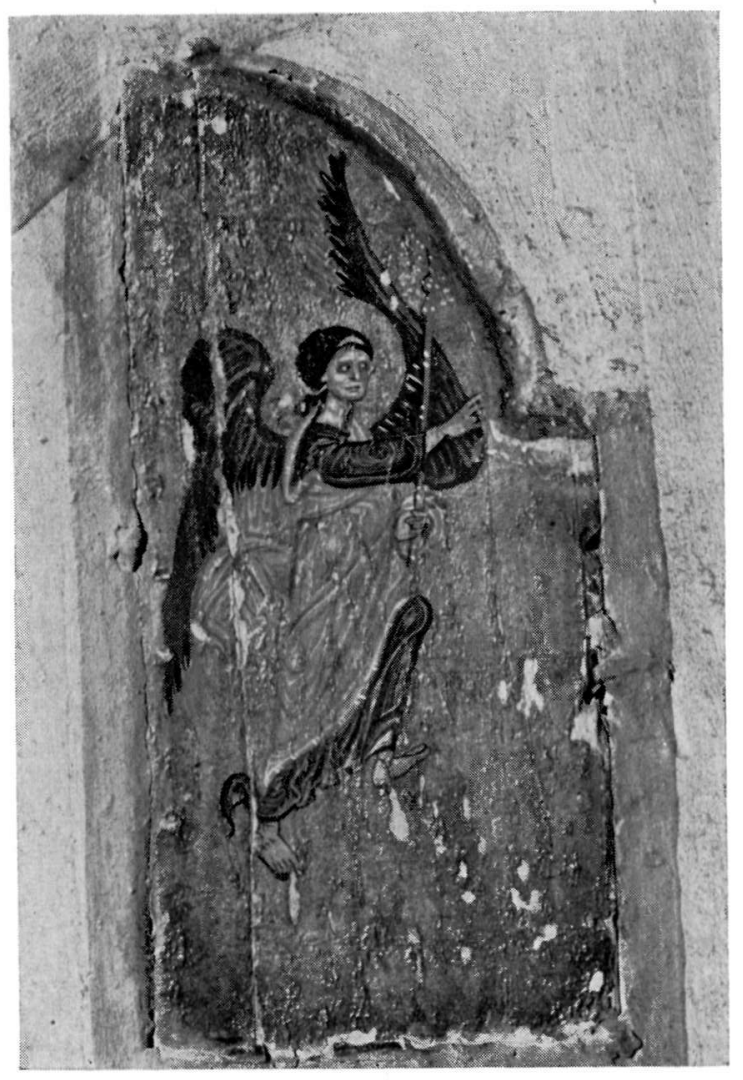

Fig. 12. Mt. Sinai, Arba'in. Wing with angel.

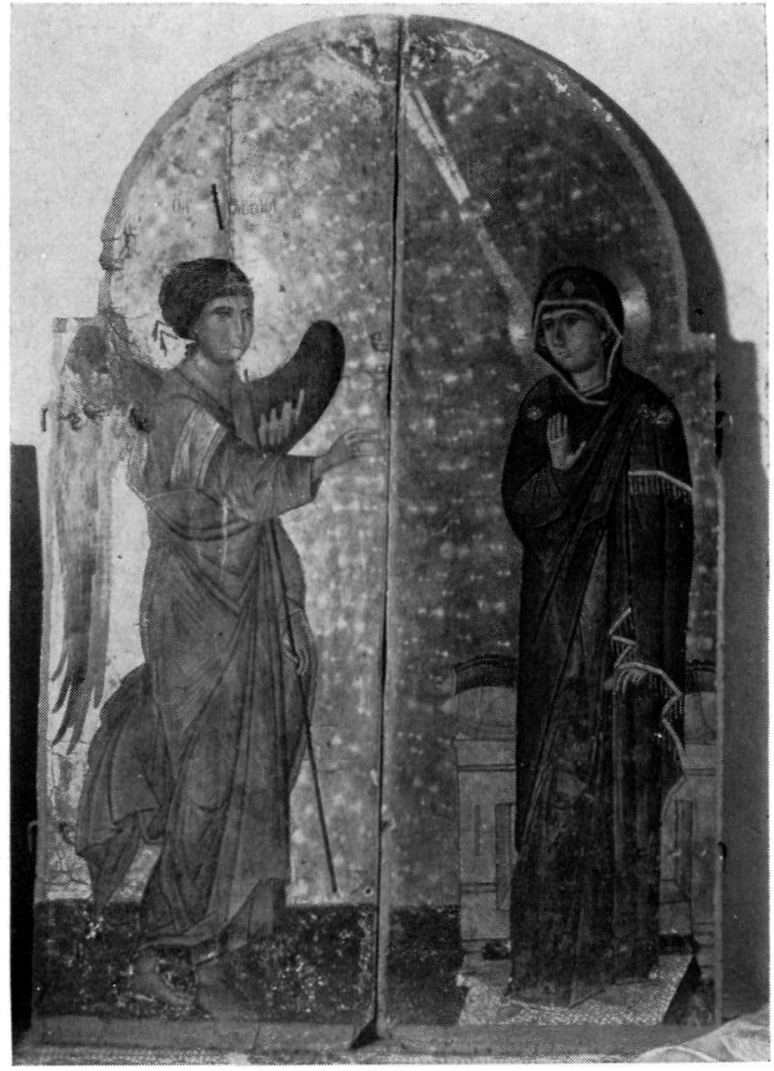

Fig. 13. Mt. Sinai, Panaghia Chapel. Royal Doors with Annunciation. 


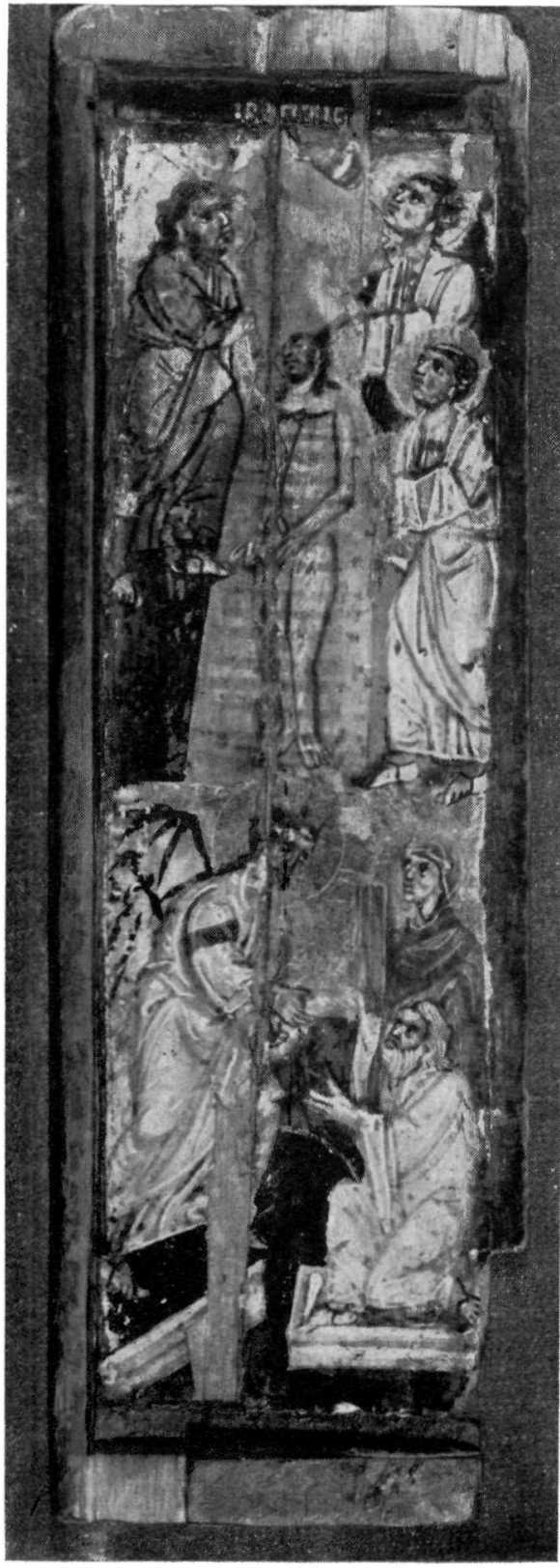

a

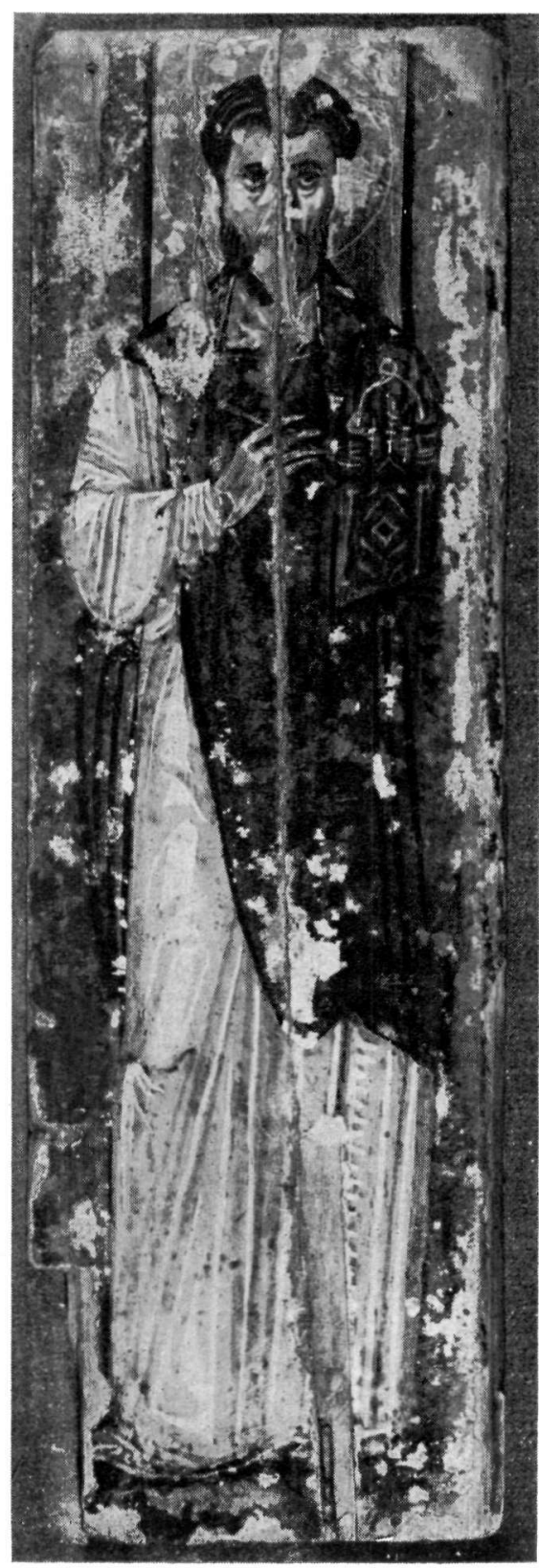

$\mathrm{b}$

Fig. 14 a-b. Mt. Sinai. Triptych wing with Cosmas, Baptism and Anastasis. 


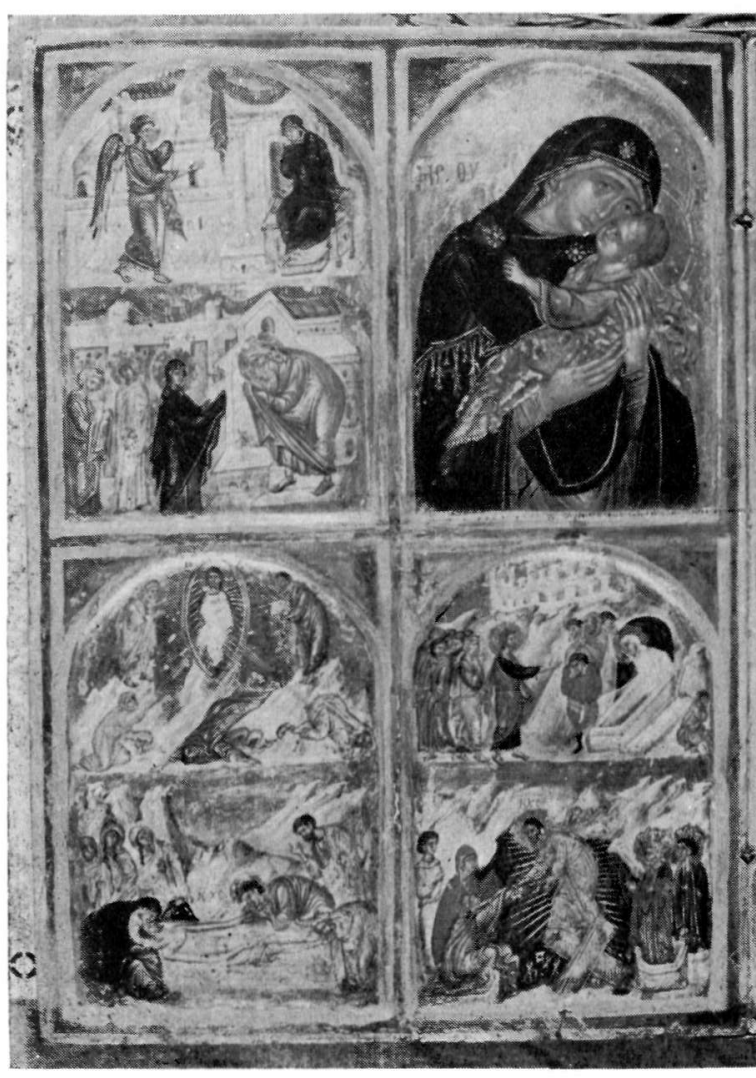

a

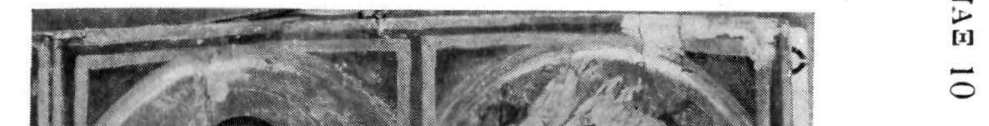

Fig. 15 a-b. Mt. Sinai. Diptych with Christ, Virgin and 12 feasts. 
the large magazine of icons in St. Catherine's the carpenter who made the Doors found an Annunciation angel from another triptych (fig. 12) ${ }^{1}$ in which it had formed a left wing, thus being part of yet another such triptych with an Annunciation on its wings. Because of the rather rough style, it is difficult to date the panel with the angel, but it surely is considerably later than the Virgin of our triptych and hardly earlier than the fifteenth century. It may well be that our Nicholas wing was sawn into two pieces only at the time when the carpenter was interested in having a Virgin as a counterpart for the wing with the angel Gabriel.

The traditional subject for the Royal Doors is the Annunciation. The placement of two triptych wings with the same subject on the Royal Doors probably indicates that the monastery at that time had no competent painter available to depict an Annunciation directly on the door valves, but was satisfied with re-using spolia from the extensive, partly stored icon collection. Among the various examples from Sinai in which the Annunciation is painted directly on the valves of the Royal Doors the earliest one is in the Lower Panaghia chapel (fig. 13) ${ }^{2}$. These panels which, on stylistic grounds, we should like to date in the thirteenth century - and not very late in it - were saved from an earlier iconostasis and re-used for the present one which, like all the others in Sinai, is not earlier than the baroque period. Standing rather stiffly so that they could be accommodated in the narrow valves, the Virgin and the Angel evoke a monumental effect which is lost in later Royal Doors where the painted area is often greatly diminished in order to give way to richly carved ornamental frames. In our case the decorative effect is achieved by tooling the golden background all over with disks of different sizes, a technique developed especially in the twelfth and thirteenth centuries for nimbi (cf. p. 11 and fig. 8) in order to create the effect of the rotation of wheels.

The Royal Doors, then, seem to be the beginning of an association of the Annunciation with the idea of door valves or wings. When one opens the Doors, whose Annunciation symbolizes the dogma of the Incarnation, the beholder is enabled to look into the inner sanctuary and become a witness to the mystery of the communion performed therein. The biblical basis for such a concept of a closed door, through which only the Lord has entered, is Ezekiel XLIV, 1 - 2 : «Then

1. It measures $21,2 \times 9,8 \mathrm{~cm}$.

2. Each valve measures $124,5 \times 38,7 \mathrm{~cm}$. 
he brought me back the way of the gate of the outward sanctuary which looketh toward the east; and it was shut. Then said the Lord unto me: This gate shall be shut, it shall not be opened, and no man shall enter in by it, because the Lord, the God of Israel, hath entered by it, therefore it shall be shut). Moreover, the close association of the Virgin, as the guarantee of Christ's humanity, with a door is a wellknown image of the VIII Oikos of the Akathistos Hymnos : "Hail! gate of hallowed mystery", or in the IV Oikos: "Hail! the heavenly gateways opening").

The association of the Annunciation with the passage through a door is visualized in still other ways in the Church building. In the Athos monastery of Vatopedi, for instance, an Annunciation, executed in mosaic, covers the walls to the left and right of the door of the exonarthex and a second such Annunciation in mosaic is inside the Church, higher up on the eastwalls to the left and right as one faces the apse '. The Annunciation is of eminent liturgical importance within the decoration of the Church, and its appearance on triptych wings strongly emphasizes that we are dealing with a liturgical object ${ }^{2}$ which in many ways has features in common with the iconostasis. Of course, the triptych makes a change in placing the Annunciation inside the wings instead of outside as on the Royal Doors, so that the idea of the Incarnation is perceived in the former only after it is opened. Even so, the idea of a progression, walking through a door or opening a triptych, is inherent in both.

\section{V}

We should like to add a few remarks about the triptych and its various forms, now that we have proposed a reconstruction of one (fig. 5) for a period from which no such painted triptychs had hitherto been found. While it was known that triptychs had existed in the Early Christian period - the evidence was based upon two rather crudely painted small wings of Egyptian manufacture, one representing the busts of two saints and the other depicting the Nativity and Baptism

1. G. Mille t, Monuments de l'Athos, Vol. I Les Peintures, Paris 1927, pl. 4 No $2-3$ and pl. 1 No $2-3$.

2. For the relation of the ivory triptychs to the liturgy cf. E. H. K a n t orowi c z, Ivories and Litanies, in : Warburg Journal V, 1942, pp. 56 ff. 
of Christ superimposed ${ }^{1}$ - only the Sotirious' publication has produced further evidence, that in this early period these were not isolated cases and confined only to Egypt, but a very common and wide-spread form of icon painting.

It may not always be possible to detect a central panel from a triptych after it has lost its wings, but the latter, because of their particularly elongated form, can be more readily identified as such and a rather large number of the early panels from Sinai are unquestionably triptych wings. In filling their high narrow format the preferred subjects are figures of saints, either standing and taking up the entire height ${ }^{2}$ or busts, of which normally two, and sometimes even more, are superimposed ${ }^{3}$. Also, the superimposition of two standing saints already occurs in the pre-iconoclastic period ${ }^{4}$.

After the end of iconoclasm the triptych apparently remained popular, and it can hardly be considered accidental that among the very few Sinai icons which can be attributed to the tenth century, several triptych wings occur. For one pair which depicts the apostle Thaddaeus and King Abgarus in the upper register and a row of standing saints in the lower ${ }^{5}$ we have attempted a reconstruction and suggested appropriate subjects for the missing central panel ${ }^{6}$. There is in Sinai yet another small triptych wing of quite similar style and also tenthcentury (fig. $14 \mathrm{a}-\mathrm{b})^{7}$ which differs from those previously discussed in two respects. First, the outside of the wing, hitherto if decorated at all then only with a cross, is occupied by a frontally standing physician saint with a medicine box who is looking to the right and, therefore, must have been on a left wing. Almost certainly he is St. Cosmas, requiring a corresponding figure of St. Damian on the lost right wing. Using both sides of a wing for representational art may well have been an innovation of the Middle-Byzantine period since it does not, to the extent of our present knowledge, occur on any preiconoclastic example. The second point is the depiction of christological

1. O. Wulff-M. Alp a t of f, Denkmäler der Ikonenmalerei, Hellerau 1925, p. 15 fig. 5, p. 32 fig. 13 and p. $257,259$.

2. S o ti r i o u, op. cit. p. 29 and figs. $14-15$; p. 44 and figs. $30-31$.

3. Ibidem, p. 35 and fig. 20,22 ; p. 43 and fig. 29.

4. Ibidem, p. 36 f. and fig. 21.

5. Ibidem, p. 49 ff. and figs. $34-36$.

6. K. Weitzmann, The Mandylion and Constantine Porphyrogennetos, in: Cahiers Archéologiques, To. XI, 1960, pp. 163 ff.

7. Is measures $28 \times 8,6 \mathrm{~cm}$. 
scenes instead of saints on a triptych wing. Here, the small Egyptian wing with Nativity and Baptism already mentioned, although it is very difficult to date, seems to have set a precedent for their use in this place in the pre-iconoclastic period. Our pair of pre-iconoclastic wings also (fig. $10 \mathrm{a}-\mathrm{b}$ ), which depicts the Annunciation, may be mentioned in this connection in spite of the division of this scene into two parts, and although it does not involve a more complete feast cycle. Baptism and Anastasis which are represented on our 10th - cent. wing are two of the great feasts and it is quite justifiable to assume that the other wing contained two more feasts, but with regard to the center, it is impossible to determine whether one feast occupied the whole or whether it contained two and possibly even four scenes. Yet, no matter how the triptych is devided there was no space to accommodate the full cycle of the twelve feasts. Actually, parallels can be cited among the tenth-century ivories for all three possibilities of filling the central panel. A triptych in the Louvre ${ }^{1}$ depicts the Nativity alone in the center and on the left wing superimposed the Entry into Jerusalem and the Anastasis (the latter, therefore, in the same place as it is on our painted wing) and at the right an Ascension of Christ. Another triptych in Munich \&, taken apart and made into bookcovers, has the Crucifixion in the center in an upper zone and the Deposition and Entombment in the lower, while the wings even comprise three superimposed scenes. It may be noted that the sequence of the scenes on these wings is to be read horizontally, in this respect setting a precedent for the arrangement of the scenes from the life of St. Nicholas in our reconstruction (fig. 5). Finally, in Quedlinburg there is the center of a triptych ${ }^{3}$, to which the wings are lost, depicting four scenes arranged in cross form.

The ivories are of particular importance for the Byzantine art of the tenth century, since they are the richest material we have for this most flourishing phase of the period of the Macedonian emperors and, being to a large extent dependent upon icon painting, they fill a serious gap in the history of the latter. Among the ivories the triptych outweighs by far any other form of panel, and since there is no reason to assume that conditions were different with regard to the painted panels, it is more than likely that in the tenth and probably into the

1. Gold s ch midt - W e it z m a n n, op. cit., pl. II, 4 .

2. Ibidem pl. VI, 22.

3. Ibidem pl. XXIX 74a and 75a. 
eleventh century the triptych was, whatever the medium, the predominant form of icon at least among those of a small format which were meant for private worship.

In going through the ivory corpus one will find all the variants repeated which we have already discussed for the pre-iconoclastic period, and thus one gets the distinct impression that in this respect the post-iconoclastic period merely adopted the old tradition. There are wings depicting single standing saints like those showing the Emperor Constantine and St. Theodore ${ }^{1}$, others with superimposed busts ${ }^{2}$ and again, quite frequently, some with two rows of standing saints ${ }^{3}$. A formal change is the introduction of a semicircular termination of the triptych which, when opened, shows each wing crowned by a quarter circle ${ }^{4}$. Since no evidence for this shape has been found so far in pre - iconoclastic icon painting, it may very well have been an innovation of the tenth century. Among the Sinai icons its earliest appearance is an eleventh-century triptych center ${ }^{5}$ which depicts scenes from Christ's infancy grouped around a central Nativity. Of course, there is no reason why, as in the ivories, this form should not have already been in use in the tenth-century painted icons. Returning to our Nicholas triptych (figs. 4-5), its trilobed termination has no counterpart in any tenth - century ivory triptych and, therefore, may have been developed no earlier than the eleventh century and may be understood as an elaboration of the simpler form of a semicircle.

The Nativity icon just mentioned is interesting from still another point of view. While on the tenth - century ivories wherever the Nativity occupies the center of a triptych ${ }^{6}$, it is surrounded by only the Washing of the Child and the Annunciation to the Shepherds and, on occasion, by the Adoration of the Magi, the expansion into a fuller narrative of the Infancy story must be considered an innovation of about the period in which this icon was made, i. e. the eleventh century, and this expansion involves the copying of a miniature cycle. This, then, is obviously a parallel to our Nicholas icon where the illustration of the life of the Saint in narrative form also occurred for the first time in this period. It is true that on one of the pre-iconoclastic

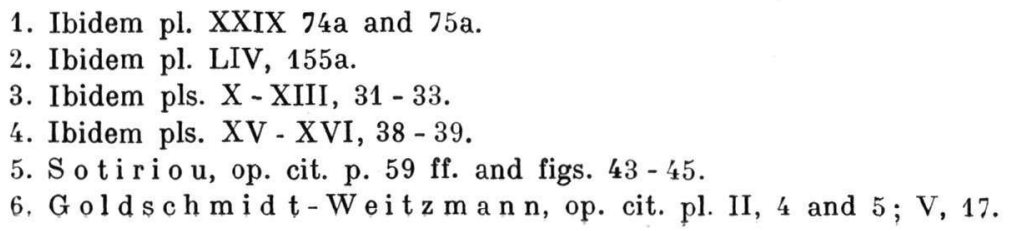


pairs of wings on Sinai (fig. $10 \mathrm{a}-\mathrm{b}$ ) the figure of Peter on one wing was shown opposite a scenic representation involving Paul and Thecla on the other, but this does not yet constitute a narrative cycle. Similarly, in the tenth - century ivory triptychs the saints occur singly or in rows, notwithstanding that a central plaque may contain an individual episode from the lives of saints such as that of the Forty Martyrs of Sebaste ${ }^{1}$. However, this familiar composition seems to be derived from monumental painting ${ }^{2}$ and once more does not involve a narrative cycle. In analogy to the Nativity icon we may therefore. assume that a narrative cycle from the life of a saint was not likely to have been introduced into icon painting before the eleventh century. Our triptych, though not necessarily the first, may very well have been one of the very earliest such examples. The increased popularity of the Lives of the Saints as the result of their collection and new edition by Simeon Metaphrastes in the second half of the tenth century may well explain the greater availability of illustrated hagiographical manuscripts.

What still requires some brief comment is the very peculiar arrangement of our reconstructed triptych (fig. 5 ) whereby the bust of St. Nicholas occupies only the upper half of the center, while the narrative cycle surrounds it on three sides. We do not know of any exact parallel to this layout in a triptych, but in principle it resembles that of a Palaeologan diptych on Sinai (fig. $15 \mathrm{a}-\mathrm{b}$ ) ${ }^{3}$, in which the upper inner panels are occupied by a bust of a Virgin with Child and a bust of a Pantocrator Christ surrounded on three sides by representations of the twelve feasts. Their sequence is to be read horizontally in such a manner, that one must jump from the Annunciation on the left wing to the Nativity on the right, and once more in the second row from the Presentation in the Temple to the Baptism, then in the third and fourth rows the reading is continuous from the Transfiguration to the Crucifixion in the one row and the Bewailing to the Pentecost in the other ${ }^{4}$. The parallelism to our Nicholas triptych (fig. 5 ) is obvious and we believe this greatly strengthens the credibility of our reconstruction.

The form of the triptych remained in use as long as icon painting

1. Ibidem pl. III, $9-10$.

2. O. Demus, Two Palaeologan Mosaic Icons in the Dumbarton Oaks Collection, in : Dumbarton Oaks Papers XIV, 1960, p. 96 ff.

3. Each wing measures $35 \times 25 \mathrm{~cm}$.

4. This cycle deviates from the normal one in that the Bewailing, the Threnos, as part of the Deposition, follows the Crucifixion and therefore leaves no space for the Koimesis at the end. 
existed, i. e. well into the eighteenth century, but already in the twelfth century it seems to have lost its dominant position among the portable icons. This is clearly indicated by the fact that in our particular case of the St. Nicholas icon the arrangement of our triptych was not repeated, but gave way to a new arrangement whereby the narrative cycle was placed like a wreath on the frame of the icon, and not only in the case of the St. Nicholas icon but in those of other saints as well such as St. Catherine, St. George, or St. John the Baptist ' It is quite conceivable that in these cases also the frame-cycle was preceded by another arrangement similar to that of our triptych, and in all these cases we feel justified in assuming illustrated books as the ultimate source, so that, vice versa, this type of icon helps to fill a lacuna in our material of illustrated manuscripts.

What is the reason for the popularity of the triptych? Basically, it is not a problem of aesthetics or utilitarianism. The explanation is, we believe, provided by the similarity of its form to that of the Royal Doors of the iconostasis, as discussed above. When the worshipper takes a closed triptych into his hands, he faces it with an expectation similar to that which he feels when standing in a church in front of an iconostasis. The opening of the triptych wings creates the sensation of having an inner sanctuary revealed comparable to the opening of the Royal Doors thus permitting a glance into the bema and allowing the worshipper to become a participant in the mysterium.

KURT WEITZMANN

1. Sotiriou, op. cit. p. 147 ff. and figs. 166-169. 